\title{
GIS-based Modeling of Debris Flow Runout Susceptibility in Kulekhani Watershed, Nepal
}

\author{
Bhuwani Paudel, Mamadou Fall, Bahram Daneshfar \\ University of Ottawa \\ 800 King Edward Ave, Ottawa, ON K1N 6N5, Ottawa, Canada \\ bpaud101@uottawa.ca; mfall@uottawa.ca; bdaneshfar@uottawa.ca
}

\begin{abstract}
Rainfall-induced landslide masses often change into disastrous debris flows and damage large areas in Nepal's mountainous region. The area covered by debris flow inundation is a most essential component for landslide hazard assessments leading to development of land use plans for saving lives and property. Because debris flow is a complex natural phenomenon, runout analysis requires very detailed information and rigorous procedures. Various empirical and dynamic models are available for debris flow runout simulation. However, a simple and publicly accessible model that can provide reasonable results is the ideal option for engineers and scientists. The Flow-R model with various algorithms has the capability to analyze debris flow inundation with limited input information, and the model software is readily available in the public domain. In this research, the Flow-R model with user-defined landslidesusceptible areas for a single rainfall event (540 mm in 24 hours) was chosen for debris flow runout analysis in Kulekhani Watershed (Nepal). The results obtained from this modeling for the debris flow inundation area was $2.68 \%$ of the watershed. The result is comparable to previously observed debris flow area in the study watershed.
\end{abstract}

Keywords: Debris Flow, Runout, Landslide, Kulekhani, Nepal.

\section{Introduction}

Debris flow is one of the most severe natural calamities among all forms of landslides in mountainous regions. Rainfall is one of the prime triggering factors for the formation of a debris flow from the initial landslide. Nepal's mountainous areas are densely populated, and human life and property are vulnerable to such rainfall-induced wide-spreading debris flows. As mountainous regions are prone to debris flows, prediction and remedial measures are important factors to consider for saving lives and property. Rainfall-induced shallow landslides that change into debris flows travel large distances on sloped natural terrain, and debris flows spread over more area compared to their initial landside source location. Both the initiation locations and runout areas of debris flows are required for hazard analysis in these mountains. People reside in the middle mountains and low valleys of Nepal despite vulnerability to debris flows and high risk of loss of lives and property. Every year many people lose their lives and property as a result of such calamities.

Recently, a number of studies have been conducted on landslide dangers for those living in these mountains [e.g. 1-2]. However, debris flow runout from the initial landslide and its analysis at the watershed scale has not yet been studied for hazard assessment. Therefore, modelling for debris flow runout analysis is the objective of this research. In this study, the initially identified landside susceptibility area is employed for identification of corresponding debris flow runout and inundation map, which can be used further for watershed hazard and risk analysis.

\section{Runout Modelling}

The runout distance of a debris flow can be predicted by solving momentum conservation equations [3], travel angle [45] and debris volume methods [6]. Reach angle or travel angle $(\alpha)$ is one of many empirical methods proposed by many researchers for runout analysis. Debris flow modeling with dynamic analysis (DAN) was proposed by [7] with Voellmy, friction and quadratic rheology, by [8] with FLO2D, by [9] with RASH3D. For applying some of these methods, the debris flow rheology is necessary from all locations of the watershed. Finding the debris flow rheology for each location in the watershed is complex and not practicable for professional practice at a reasonable cost. In this research, an empirical model that is publicly available, Flow-R [10], is applied to determine the debris flow runout. 


\section{Methodology}

In this study, the landslide susceptibility map previously developed by [11] for the study watershed, procedure shown in Figure 1, was considered for debris flow source. For runout, the empirical method, the Flow-R model with modified Holmgren model [12], and the aforementioned susceptibility map (source area) were considered. Flow- $\mathrm{R}$ is an empirical model developed by the University of Lausanne. Among various options in Flow-R, modified Holmgren model [12] was appropriate for debris flow runout modelling in the study region [11]. The digital elevation model (DTM) of the watershed and landslide source maps were converted into an ASCII file in GIS software and applied to the runout analysis. The final results from Flow-R were compiled with the watershed map back in GIS. The final map shows the landslide initiation and debris flow spreading areas resulting from the selected rainfall event in the study watershed. The procedures for debris flow source map and runout maps development in this research is shown in Figure 1. The process of obtaining Landslide Susceptibility Maps within the procedures related to Data Acquisition and Database to Debris Flow Inundation Maps [Figure 1.] is given in [11].

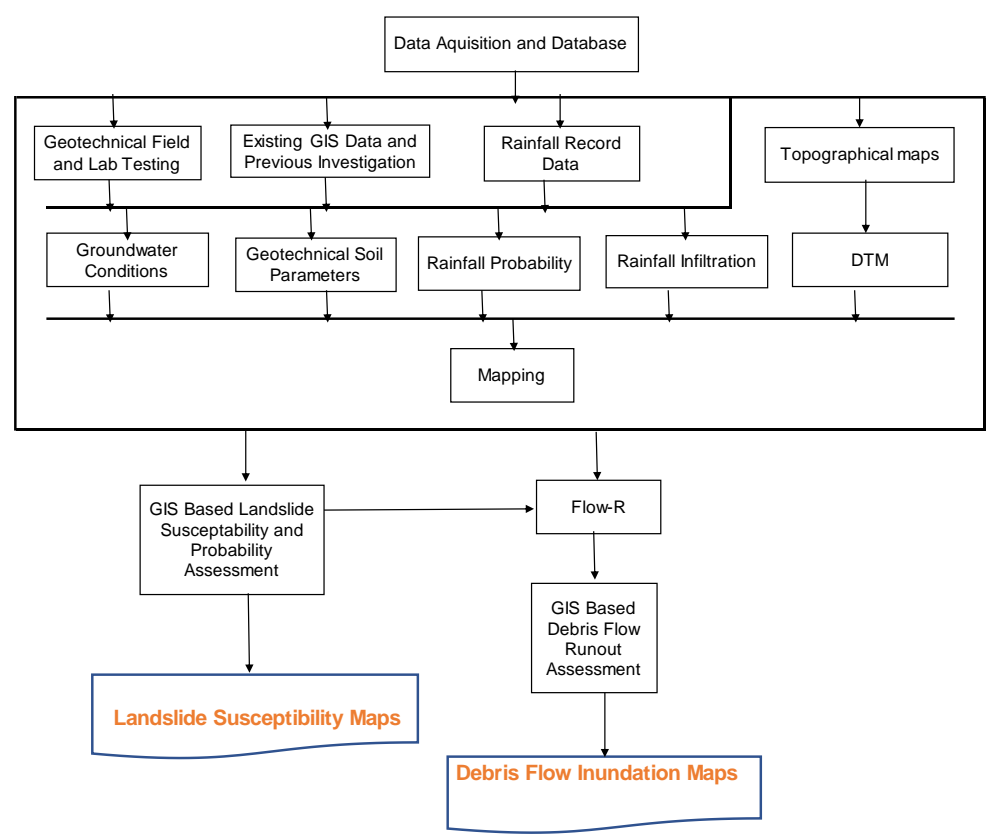

Fig. 1: Flow Chart for debris flow source and inundation maps.

In the Flow-R model, the flow mass is considered as a unit value and energy loss is entirely from friction. The energy required to travel to another cell must be sufficient for flow to take place from one cell to another. Energy is the controlling factor for total runout and also for spreading to side cells based on the difference between the available energy and provided energy between two cells or cells adjacent to the central cell as shown in Equation [1] ([10]).

$$
E_{k i n}^{i}=E_{k i n}^{o}+\Delta E_{p o t}^{i}-E_{f}^{i},
$$

where $E_{\text {kin }}^{i}$ is the kinetic energy of the cell in direction i, $E_{\text {kin }}^{o}$ is the kinetic energy of the central cell, $\Delta E_{\text {pot }}^{i}$ is the change in potential energy to the cell in direction $\mathrm{i}$ and $E_{f}^{i}$ is the energy lost in friction to the cell in direction i. The friction loss can be assessed by two types of algorithms: a two-parameter friction model by [13] and a simplified frictionlimited model (SFLM). 


\section{Study Area}

The study watershed is in the middle hills of Nepal among three geographical regions, High Himalayas, Middle Mountains and Terai (plains area) (Figure 2a.). The highway distance is about $57 \mathrm{~km}$ from Kathmandu, the capital city of of Nepal. A total of $16 \%$ of the land area of Nepal is covered by high mountains which includes 8 high peaks that are among among the 14 highest peaks in the world. The height of the middle hills ranges from 500 to $3000 \mathrm{~m}$, and this zone covers $67 \%$ of the total land area of the country, while the lowest plains area accounts for $17 \%$. The study area represents the middle hills (67\%) of Nepal which are densely populated and prone to debris flow. In Nepal among approximately 30 million people, $52 \%$ are living in steep slopes and small valleys of the high and middle mountain zones similar to the morphology of the study watershed of this research.

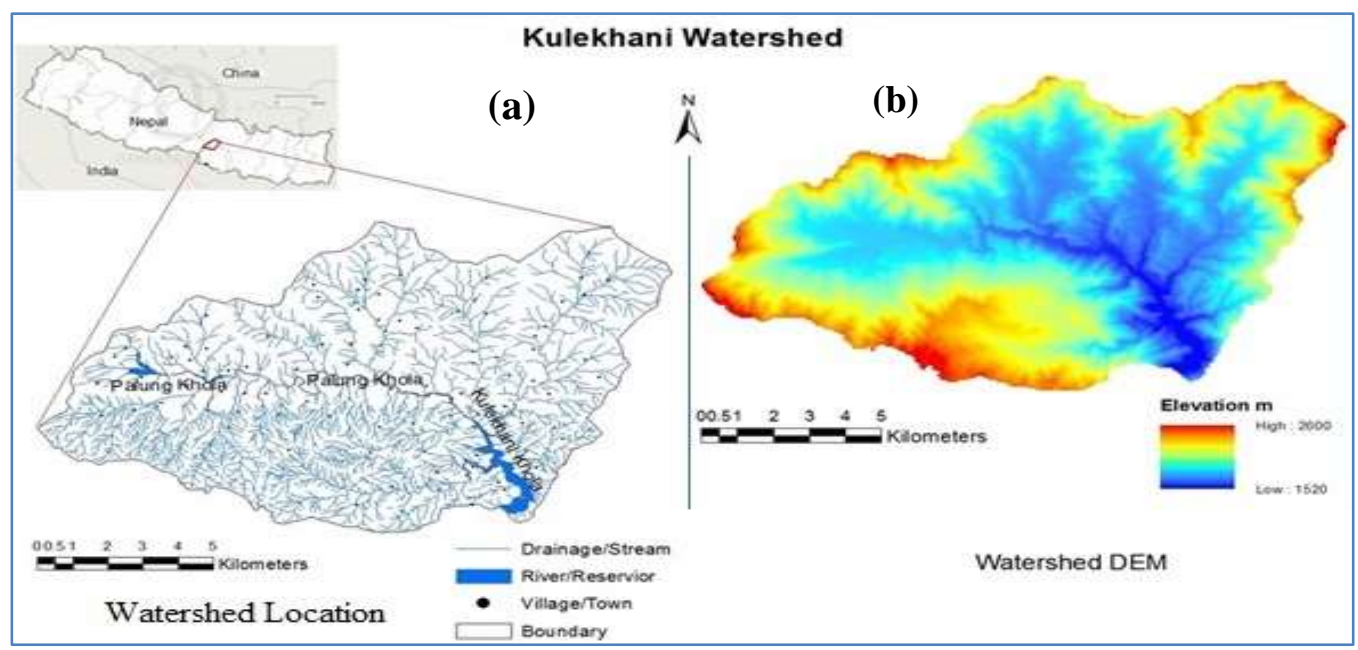

Fig. 2: (a) The study area Location, (b) Digital Elevation Model (DEM).

The study watershed has an approximately $124 \mathrm{~km}^{2}$ drainage area. The elevation of the study area ranges approximately from 1500 to $2621 \mathrm{~m}$ above sea level (Figure 2b.). This watershed is located within Latitudes of $27^{\circ} 35^{\prime} 04^{\prime \prime} \mathrm{N}$ to $27^{\circ} 41^{\prime} 00^{\prime \prime}$ $\mathrm{N}$ and Longitudes of $85^{\circ} 02$ '22'E to $85^{\circ} 12^{\prime} 8^{\prime \prime}$. The major rivers are Palung Khola and Kulekhani Khola.

\section{Results}

The unstable area from the 1993 extreme rainfall event (540 $\mathrm{mm}$ in 24 hours) was modelled in this study for debris flow runout, and the results is shown in Figure 3. The unstable locations from the model in the watershed was $1.38 \%\left(1.715 \mathrm{~km}^{2}\right)$ of the total area. The model study results are comparable with the debris flow initiation area observed $\left(2.35 \mathrm{~km}^{2}\right)$ by [2]. The areas observed are comparatively more than the predicted area by model study (single event of $540 \mathrm{~mm}$ rainfall) because observed areas were accumulated landslide-initiated areas over the several years with multiple events. The debris flow spreading area from the model was $2.68 \%$ of the total watershed $\left(3.325 \mathrm{~km}^{2}\right)$ or 332.53 hectares. The ratio of spreading area to source area for this extreme case is about 2:1. The result was compared to debris flow in other minor events studied by [11] for the study watershed and was understood that the debris flow source to spreading ratio decreases with minor to major (extreme) events.

\section{Conclusion}

Rainfall-induced landslides frequently change into debris flows and devastate large areas in mountainous Nepal. Both the initial landslide and debris flow inundation locations are important considerations for landslide hazard analysis. Debris flow runout assessment requires a large amount of information and computational processing. In this study, the Flow-R model was applied to assess and predict debris flow runout in the study area. The validation results have shown that the 
Flow-R model can predict well the debris flow inundation areas from rainfall-induced initial landslides. The results show that the debris flow spreading covers $2.68 \%$ of the total area for the extreme rainfall event that occurred in the region in 1993, which is comparable to previously observed debris flow area in the study watershed. The developed tool for of debris flow runout will be useful for debris flow hazard and risk assessment in Nepal's mountainous areas, and thus saving life and property. The findings of this research and GIS simulation tool developed will also enable the of planning and investment for land development in the studied region.

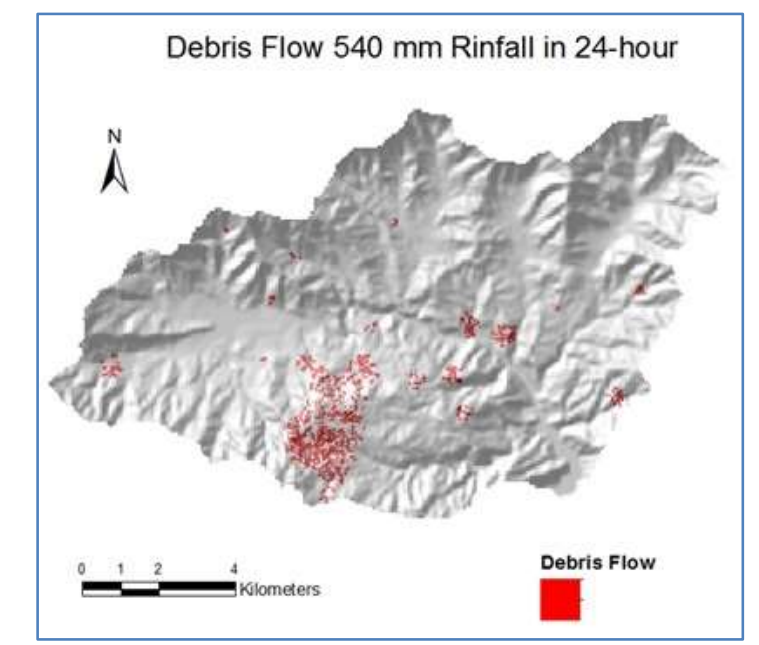

Fig. 3: Modelled Debris flow in $540 \mathrm{~mm}$ rainfall event.

\section{Acknowledgements}

The field work for this research was funded by the International Development Research Centre (IDRC) Canada through a Doctoral Research Award for the first author.

\section{References}

[1] M. R. Dhital, "Causes and consequences of the 1993 debris flows and landslides in the Kulekhani watershed, central Nepal, Debris-flow Hazards Mitigation: Prediction and assessment," Rickenmann \& Chen (eds), pp. 1931 - 1943, 2003.

[2] P. Kayastha, M. R. Dhital, F. D. Smedt, "Evaluation and comparison of GIS based landslide susceptibility mapping procedures in Kulekhani watershhed, Nepal," Journal of Geological Society of India, vol. 81, pp. 219-231, 2013.

[3] C. Wang, S. Li and T. Esak, "GIS-based two-dimensional numerical simulation of rainfall-induced debris flow," Nat. Hazards Earth Syst. Sci., vol. 8, pp. 47-58, 2008.

[4] H. N. Wong, K. C. Lam and K. K. S. Ho, "Diagnostic report on November 1993 Natural Terrain Landslides on Lantau Island," GEO special report, no. 6, 1993.

[5] M. Hurlimann, D. Rickenmann, V. Medina and A. Beteman, "Evaluation of approach to calculate debris-flow parameters for hazard assessment," Engineering Geology, pp. 152-163, 2008.

[6] D. Rickenmann, "Empirical relationships for debris flows,” Nat. Hazards, vol. 19, pp. 47-77, 1999.

[7] O. Hungr, "A model for the runout analysis of rapid flow slides, debris flows, and avalanches," Canadian Geotechnical Journal, vol. 32, pp. 610-623, 1995.

[8] J. S. O'Brien, P. Y. Julien and W. T. Fullerton, "Two-dimensional water flood and mudflow simulation," J. of Hydraulic Engineering, ASCE, pp. 224-259, 1993.

[9] M. Pirulli and A. Mangeney, "Results of back-analysis of the propagation of rock avalanches as a function of the assumed rheology," Rock Mech. Rock Eng., vol. 41, pp. 59-84, 2008. 
[10] P. Horton, M. Jaboyedoff, B. Rudaz and M. Zimmermann, "Flow-R, a model for susceptibility mapping of debris flows and other gravitational hazards at a regional scale," Nat. Hazards Earth Syst. Sci., pp 869-885, 2013.

[11] B. Paudel, "GIS-based assessment of debris susceptibility and hazard in Nepal," PhD thesis, University of Ottawa, 2018.

[12] P. Holmgren, "Multiple flow direction algorithms for runoff modelling in grid-based elevation models: An empirical evaluation," Hydrol. Process., vol. 8, pp. 327-334, 1994.

[13] R. Perla, T. T. Cheng and D. M. McClung, "A two-parameter model of snow-avalanche motion," J. Glaciol., vol. 26, pp. 197-207, 1980. 